EGU21-14003

https://doi.org/10.5194/egusphere-egu21-14003

EGU General Assembly 2021

(c) Author(s) 2022. This work is distributed under

the Creative Commons Attribution 4.0 License.

\title{
Integrated geophysical investigations of deeper stratigraphy of the Irish Rockall Basin
}

\author{
Gaurav Tomar ${ }^{1,2}$, Srikumar Roy ${ }^{2}$, Christopher J. Bean ${ }^{1,2}$, Satish C. Singh ${ }^{3}$, Brian O'Reilly,2, and \\ Manel Prada 4 \\ ${ }^{1}$ Dublin Institute for Advanced Studies, Cosmic Physics, Dublin, Ireland (gauravtomar63@gmail.com) \\ ${ }^{2}$ Irish Centre for Research in Applied Geosciences (iCRAG), Dublin, Ireland, \\ ${ }^{3}$ Institut de Physique du Globe de Paris, France \\ ${ }^{4}$ ICM-CSIC, Barcelona-CSI, Geosciences, Barcelona, Spain
}

The Rockall Trough is an elongate bathymetric depression trending NNE-SSW. It is approximately $1200 \mathrm{~km}$ long and up to $300 \mathrm{~km}$ wide, extending over the UK and Irish continental margins. The trough is underlain by the Rockall Basin, which forms part of a chain of late Paleozoic-Cenozoic sedimentary basins. The Irish Rockall Basin is vastly unexplored as compared to the UK sector, where extensive flood basalt lava flows, sill complexes and volcanic centers of Late Cretaceous-toEarly Eocene age have been described, which belong to the North Atlantic Igneous Province (NAIP) (Archer et al., 2005). An integrated study of seismic, gravity and magnetic methods elucidates the deeper stratigraphy of the Irish Rockall Basin. More than $10 \mathrm{~km}$ of sediments is present in the central part of the basin. We perform first arrival travel time tomography on a downward continued data set of three seismic profiles to model the velocity of the sedimentary structures down to $6 \mathrm{~km}$ depth. To better understand the deep structure of the basin we need to estimate the Moho depth from constrained gravity modelling. The modelling results indicate that the Moho depth varies from $12 \mathrm{~km}$ to $20 \mathrm{~km}$ depth beneath $\sim 10 \mathrm{~km}$ thick sediments in the basin. This allows us to measure the crustal stretching factor $\beta$. The minimum stretching factor in the basin varies between $\sim 7$ in the north to $\sim 6.5$ in the south. These values are within the range needed for mantle serpentinisation (O'Reilly et al., 1996; Perez-Gussinye and Reston, 2001). Furthermore, we observe four volcanic ridges in the south part of the basin, which are $\sim 20 \mathrm{~km}$ wide and $\sim 3 \mathrm{~km}$ thick, possibly comprising the Barra Volcanic Ridge System (BVRS) (Scrutton and Bentley, 1988). Results indicate several failed rifting attempts times in late Mesozoic/early Cenozoic times, generating significant basic volcanism, associated with the NAIP. We resolve new volcanic ridges (of late Mesozoic/early Cenozoic age) in the southern part of the Rockall Basin, like many other volcanic ridges/centres observed in other parts of the basin, with correlatable magnetic and gravity anomalies. These may be of late Cretaceous age similar to those found on the conjugate Canadian margin. 